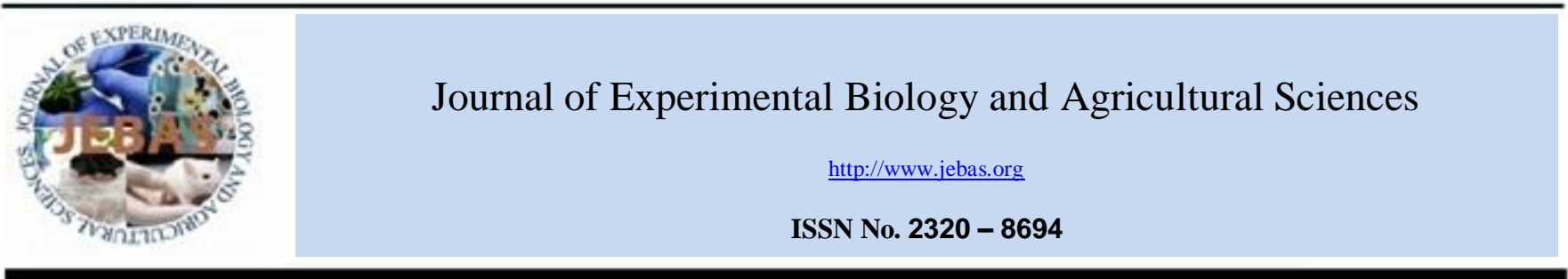

\title{
GROWING CONDITION INFLUENCES VARIATION IN INITIATION TO WILTING OF FLOWERS OF WINTER ANNUALS
}

\author{
Bikash Bhattarai*1 $^{1}$, Soumen Maitra ${ }^{2}$, Rocky Thokchom ${ }^{3}$ \\ ${ }^{1}$ Research Scholar, Department of Horticulture, Sikkim University, $6^{\text {th }}$ Mile Samdur, Tadong, Gangtok - 737102, Sikkim, India \\ ${ }^{2}$ Department of Floriculture, Medicinal and Aromatic Plants, Faculty of Horticulture, Uttar Banga Krishi Viswavidyalaya, Pundibari, Cooch Behar - 736165, \\ West Bengal, India \\ ${ }^{3}$ Department of Floriculture, School of Horticulture, Pandit DeenDayal Upadhyay Institute of Agricultural Sciences, Utlou, Bishnupur- 795134, Manipur, India.
}

Received - April 16, 2019; Revision - May 28, 2019; Accepted - June 07, 2019

Available Online - June 10, 2019

DOI: http://dx.doi.org/10.18006/2019.7(3).281.288

\section{KEYWORDS}

Ornamental annuals

Winter annuals

Flowering period

\section{ABSTRACT}

Present study was conducted to study the differences in flowering behavior of twenty different ornamental winter annuals, mostly used for landscaping purpose under different agro-climatic conditions, in the Terai region of West Bengal, India under open field and protected condition. Flowering parameters such as Days required for flower bud initiation (FBI), Days required for flower bud development (FBD), Days required for blooming, Days required for wilting of flower were recorded in each plot and their average was calculated. Calendula officinalis showed earliness in FBI (23.25 DAT), FBD (32.88 DAT), blooming (35.50 DAT) and wilting (43.00 DAT) under open condition and the late flowering was found in Antirrhinum majus (74.67 DAT), whereas, the delayed wilting was observed in Helichrysum bracteatum (94.30 DAT) both under protected condition. Iberis umbellata required minimum time period (6.17 days) to reach flower bud development from flower bud initiation stage. The shortest period for wilting of flowers was recorded in Eschscholtzia californica (2.00 days) under protected condition, while, Helichrysum bracteatum required the maximum time period (21.84 days) from blooming to wilting.
* Corresponding author

E-mail: bikashflori@gmail.com (Bikash Bhattarai)

Peer review under responsibility of Journal of Experimental Biology and Agricultural Sciences.

Production and Hosting by Horizon Publisher India [HPI] (http://www.horizonpublisherindia.in/).

All rights reserved.
All the article published by Journal of Experimental Biology and Agricultural Sciences is licensed under a Creative Commons Attribution-NonCommercial 4.0 International License Based on a work at www.jebas.org.

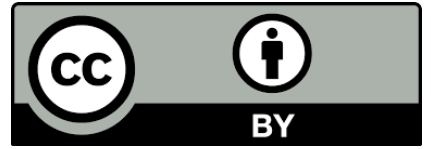




\section{Introduction}

An annual plant is a plant that completes its life cycle within a particular growing season of the year. Whereas, annual plant which having short period of lifespan is known as flowering annuals. Plants which are sown during winter months starting from October to first week of November and flowering commences within February are called as winter flowering annuals or winter annuals for the plains. (Randhawa \& Mukhopadhyay, 1986) Plants with strong vernalization requirement are often referred as winter annuals. Winter flowering annuals provides excellent relaxation, attracts people when planting in a mass and serve as beautification in any landscape plan (Brown, 2012). Annuals are also used as bedding plants, rockery, window baskets, garden plants and herbaceous borders in garden

Flowering in plant is an inductive process which includes initiation of floral meristem in which the apical meristem modified towards floral development (McDaniel et al., 1992). Murfet (1977) summarized as the flowering is the end result of physiological processes, biochemical sequences, and gene action, which are influenced by environmental stimuli and the passage of time (Munir 2003; Zheng et al., 2006) as well as genotype; a genotype can take two seasons to flower in an environment whereas it may flower within a single season in different environment. Usually, after completing of juvenile and developmental phases plants go through reproductive phase responding to the environmental factors (temperature, photoperiod). The literatures related to the winter annuals like effects of differential temperature on the growth, morphology and flowering of Antirrhinum majus, flower production of calendula, growth and flowering of Californian poppy, Helichrysum bracteatum, Coreopsis, Cornflower, Sweet Williams (Krogt, 1980; Kanamadi et al., 1999; Kazinczi et al., 1999; Shang et al., 2003; Mili \& Sable, 2003; Singh, 2005; Dhatt \& Kumar, 2007; Ibrahim et al., 2010), flower initiation and development of Petunia and Viola (Mattson \& Erwin, 2003), responds of Calendula, Chrysanthemum, Pansy and Snapdragon to high temperatures, impact of reduce temperature and irradiance flowering and growth of four annual bedding plants (Warner \& Erwin, 2006; Boldt \& Atland, 2019) and assessment of height, earliness and biomass production in winter annuals (Bhattarai et al., 2019) revealed the variation on plant height, growth habit, shape, size, color of flowers, time and duration of flowering within the genotypes, even though these are the species of same growing season. But reports regarding the comparative study and the performance of diverse winter ornamental annuals under different growing environments are in scarcity. Winter annuals being a source of garden decoration are need precise documentation and characterization to satisfy the gardening practices and landscaping principles. In this study, an attempts have been made to study the comparative flowering behavior of twenty different winter flowering ornamental annuals both under open field and protected conditions to develop a database on the performance of ornamental annuals in the Terai region of West Bengal for more diversified use of ornamental annuals in landscape, garden display as well as in commercial floriculture.

\section{Materials and Methods}

Present experiment was carried out at the instructional field of Department of Floriculture, Medicinal and Aromatic plants, Faculty of Horticulture, Uttar Banga Krishi Viswavidyalaya, Pundibari, Cooch Behar, West Bengal, India. Experiment was designed in Randomized Block Design with 20 different winter flowering annuals, each annual were replicated twice (4 plants per each replication). The detail of the selected flowering species is depicted in Table 1. Seeds of 20 winter flowering annuals were

Table 1 Details of the winter flowering ornamental annuals used

\begin{tabular}{|c|c|c|c|}
\hline $\begin{array}{l}\text { Sl. } \\
\text { No. }\end{array}$ & $\begin{array}{c}\text { English common } \\
\text { name }\end{array}$ & Botanical name & Plant family \\
\hline 1 & Snapdragon & Antirrhinum majus L. & Scrophulariaceae \\
\hline 2 & $\begin{array}{l}\text { Pot Marigold / } \\
\text { Calendula }\end{array}$ & Calendula officinalis $\mathrm{L}$. & Compositae \\
\hline 3 & $\begin{array}{l}\text { Straw Flower / } \\
\text { Helichrysum }\end{array}$ & $\begin{array}{l}\text { Helichrysum } \\
\text { bracteatum (Vent.) } \\
\text { Andrews }\end{array}$ & Compositae \\
\hline 4 & Petunia & Petunia hybridaVilm & Solanaceae \\
\hline 5 & $\begin{array}{l}\text { Livingstone Daisy / } \\
\text { Mesembryanthemum }\end{array}$ & $\begin{array}{l}\text { Mesembryanthemum } \\
\text { criniflorum L. }\end{array}$ & Aizoaceae \\
\hline 6 & Larkspur & Delphinium ajacis L. & Ranunculaceae \\
\hline 7 & Daisy / English Daisy & Bellis perennis $\mathrm{L}$. & Compositae \\
\hline 8 & Californian Poppy & $\begin{array}{l}\text { Eschscholtzia } \\
\text { californica Cham. }\end{array}$ & Papaveraceae \\
\hline 9 & Shirley Poppy & Papaver rhoeas $\mathrm{L}$. & Papaveraceae \\
\hline 10 & Lupin & Lupinus hartwegii L. & Leguminosae \\
\hline 11 & Sweet Pea & Lathyrus odoratus L. & Leguminosae \\
\hline 12 & $\begin{array}{l}\text { Brachycome / } \\
\text { Swan River Daisy }\end{array}$ & $\begin{array}{l}\text { Brachycome iberidifolia } \\
\text { Benth. }\end{array}$ & Compositae \\
\hline 13 & $\begin{array}{l}\text { Dimorphotheca / } \\
\text { African Daisy / } \\
\text { Cape Marigold } \\
\end{array}$ & $\begin{array}{l}\text { Dimorphotheca } \\
\text { aurantiaca DC. }\end{array}$ & Compositae \\
\hline 14 & Phlox & $\begin{array}{l}\text { Phlox drummondii } \\
\text { Hook. }\end{array}$ & Polemoniaceae \\
\hline 15 & Sweet William & Dianthus barbatus L. & Caryophyllaceae \\
\hline 16 & $\begin{array}{l}\text { Coreopsis / Calliopsis } \\
\text { / Tick-seed }\end{array}$ & Coreopsis tinctoria $\mathrm{L}$. & Compositae \\
\hline 17 & $\begin{array}{l}\text { Dianthus / } \\
\text { Common Pink }\end{array}$ & Dianthus chinensis L. & Caryophyllaceae \\
\hline 18 & Candytuft & Iberis umbellata $\mathrm{L}$. & Cruciferae \\
\hline 19 & Cornflower & Centaurea cyanus L. & Compositae \\
\hline 20 & Pansy & Viola tricolor $\mathrm{L}$. & Violaceae \\
\hline
\end{tabular}


sown on October 2012 in the seed bed. Beds were prepared having a dimension of $3 \mathrm{~m} \times 1 \mathrm{~m}$ and height of the beds was maintained up to $15 \mathrm{~cm}$ from the ground level. $10 \mathrm{~g}$ seeds of each winter flowering annual $(10 \times 20=200 \mathrm{~g})$ were sown in 5 seed beds, seeds of 4 winter annuals were sown in each bed. The initial nutrient provided was $5 \mathrm{~kg}$ FYM along with $10 \mathrm{~g}$ each of $\mathrm{N}_{2}, \mathrm{P}_{2} \mathrm{O}_{5}$ and $\mathrm{K}_{2} \mathrm{O} / \mathrm{m}^{2}$. Copper oxychloride at $2 \mathrm{gL}^{-1}$ of water was sprayed as preventive measure in the seed bed twice at 10 and 20 days after the seedling emergence.

Seedlings of 28 days were transplanted in the main field with spacing varies with the genotypes (Table 2). Repeated ploughing was followed to bring land to make fine tilth. The entire experimental land was divided into raised beds measuring $1.0 \mathrm{~m} \times$ $1.0 \mathrm{~m}$ and there were 40 plots in each open field and polyhouse condition. Each bed was separated to the other through a $30 \mathrm{~cm}$ wide path in both ways. Winter flowering annuals (20 Nos.) were planted in a same manner in open field as well as in polyhouse condition. For present experiment, the glavanized iron pipe frame polyhouses having 200 gauges UV stabilized polyethylene sheet as cladding material and sides were covered with insect proof white nets with side vents open facility were used (zero energy polyhouse).

The average minimum and maximum temperature of open and protected condition varied from $7.96^{\circ} \mathrm{C}$ and $11.31^{\circ} \mathrm{C}$ during January to $30.38^{\circ} \mathrm{C}$ and $34.74^{\circ} \mathrm{C}$ during October respectively. The relative humidity of the study area varies from 41.87 to $98.03 \%$. Meteorological data for open field was obtained from Gramin Krishi Mausam Seva, AMFU-Pundibari, Coochbehar, West Bengal, India and polyhouse temperature and relative humidity were measured by digital hygrometer.Consequently, the area is warm and humid except a short spell of winter extending from December to February. The meteorological data of the study period is given in Figure 1.

\subsection{Parameters recorded:}

Flowering parameters such as days required for flower bud initiation (FBI), days required for flower bud development (FBD), Days required for blooming, Days required for wilting of flower were recorded in each plot and their average was calculated. Data were analyzed using GLM procedure of statistical system (SAS) Software (Version 9.3). Design of the experiment was based on randomized block design with two replications in both the condition and parameters were tested at the $5 \%$ level of significance.

\section{Results and Discussion}

Twenty different winter flowering ornamental annuals when grown under open and protected conditions; the flowering commences earlier in open field and later in polyhouse situation.
Table 2 Spacing of the selected Genotypes

\begin{tabular}{|ll|}
\hline Spacing & Genotypes \\
\hline $25 \mathrm{~cm} \times 25 \mathrm{~cm}$ & Daisy, Phlox, Dianthus, Californian Poppy, \\
& Petunia, Shirley Poppy, Coreopsis, Sweet \\
& William, Pansy, Candytuft \\
\hline $30 \mathrm{~cm} \times 30 \mathrm{~cm}$ & Brachycome, Ice Plant, Antirrhinum, Lupin, \\
& Cornflower, Larkspur, Helichrysum \\
\hline $50 \mathrm{~cm} \times 30 \mathrm{~cm}$ & Calendula, Dimorphotheca, Sweet Pea \\
\hline
\end{tabular}
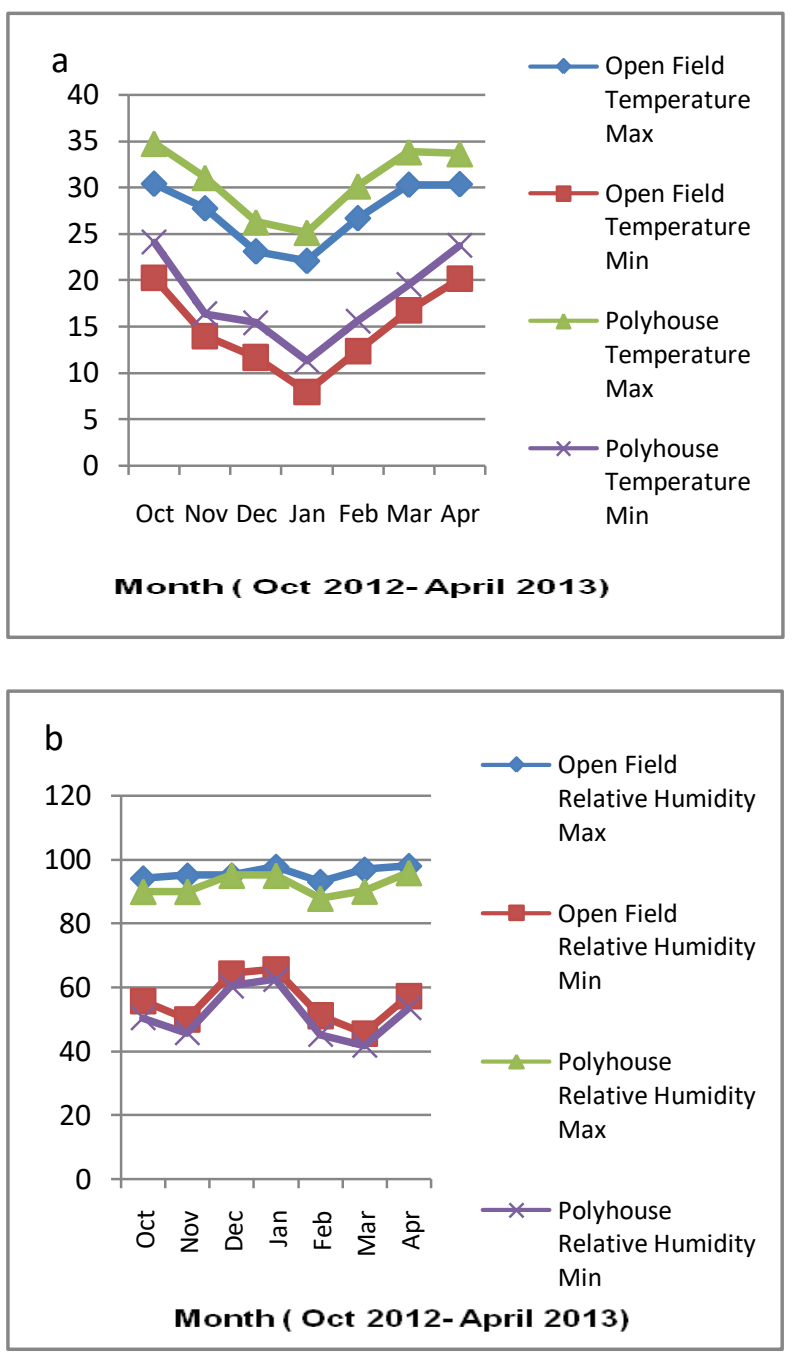

Figure 1 Monthly mean meteorological data of open field and polyhouse during the period of experiment a) Temperature and b) Relative Humidity. 
Table 3 Days required for flower bud initiation (FBI), flower bud development (FBD), blooming and wilting of winter annuals in open field and in polyhouse condition.

\begin{tabular}{|c|c|c|c|c|c|c|c|c|}
\hline \multirow[b]{2}{*}{ Genotypes } & \multicolumn{4}{|c|}{ Open field } & \multicolumn{4}{|c|}{ Polyhouse } \\
\hline & $\begin{array}{c}\text { FBI } \\
(\mathrm{DAT})\end{array}$ & $\begin{array}{l}\text { FBD } \\
\text { (DAT) }\end{array}$ & $\begin{array}{l}\text { Blooming } \\
\text { (DAT) }\end{array}$ & $\begin{array}{l}\text { Wilting } \\
\text { (DAT) }\end{array}$ & $\begin{array}{c}\text { FBI } \\
\text { (DAT) }\end{array}$ & $\begin{array}{l}\text { FBD } \\
\text { (DAT) }\end{array}$ & $\begin{array}{l}\text { Blooming } \\
\text { (DAT) }\end{array}$ & $\begin{array}{l}\text { Wilting } \\
\text { (DAT) }\end{array}$ \\
\hline Daisy & 40.00 & 46.70 & 48.90 & 58.40 & 60.88 & 68.88 & 72.63 & 80.00 \\
\hline Phlox & 43.80 & 53.50 & 55.80 & 59.30 & 54.30 & 65.10 & 67.80 & 71.10 \\
\hline Ice Plant & 39.34 & 51.75 & 55.75 & 72.00 & 62.84 & 74.50 & 77.17 & 87.84 \\
\hline Helichrysum & 38.67 & 55.00 & 60.33 & 82.17 & 53.84 & 69.10 & 75.67 & 94.30 \\
\hline Larkspur & 48.75 & 64.88 & 67.13 & 79.75 & 55.17 & 71.17 & 73.67 & 84.34 \\
\hline Antirrhinum & 47.00 & 57.17 & 60.50 & 67.33 & 74.67 & 86.17 & 89.00 & 93.17 \\
\hline Calendula & 23.25 & 32.88 & 35.50 & 43.00 & 29.34 & 39.67 & 42.17 & 49.34 \\
\hline Sweet William & 42.34 & 54.17 & 56.50 & 62.67 & 40.00 & 50.00 & 52.50 & 60.67 \\
\hline Petunia & 47.70 & 55.50 & 57.50 & 61.40 & 67.00 & 75.13 & 77.50 & 83.25 \\
\hline Lupin & 51.03 & 59.43 & 61.50 & 65.98 & 36.75 & 44.50 & 46.00 & 52.25 \\
\hline Brachycome & 45.25 & 55.75 & 58.33 & 62.92 & 62.25 & 70.50 & 73.00 & 77.25 \\
\hline Cornflower & 30.82 & 50.42 & 52.97 & 60.10 & 49.25 & 65.88 & 68.50 & 75.50 \\
\hline Dimorphotheca & 40.60 & 55.20 & 58.00 & 65.80 & 59.00 & 67.92 & 71.21 & 79.84 \\
\hline Dianthus & 45.63 & 55.88 & 58.38 & 64.50 & 48.88 & 58.50 & 61.50 & 69.50 \\
\hline Californian Poppy & 45.67 & 53.75 & 55.84 & 59.00 & 65.75 & 75.00 & 77.00 & 79.00 \\
\hline Shirley Poppy & 44.38 & 55.38 & 57.13 & 59.75 & 52.17 & 63.34 & 65.17 & 68.00 \\
\hline Pansy & 26.23 & 34.15 & 36.35 & 46.13 & 56.94 & 65.10 & 67.47 & 76.77 \\
\hline Candytuft & 31.50 & 39.34 & 41.17 & 48.33 & 34.34 & 40.50 & 42.17 & 50.00 \\
\hline Coreopsis & 34.46 & 51.09 & 53.25 & 60.59 & 44.45 & 63.73 & 65.85 & 72.80 \\
\hline Sweet Pea & 37.17 & 46.84 & 49.50 & 56.17 & 38.25 & 47.00 & 49.50 & 58.75 \\
\hline $\operatorname{Pr}>\mathrm{F}$ & $<.0001$ & $<.0001$ & $<.0001$ & $<.0001$ & $<.0001$ & $<.0001$ & $<.0001$ & $<.0001$ \\
\hline SEM & 1.27 & 1.71 & 1.80 & 1.89 & 2.51 & 2.38 & 2.38 & 2.59 \\
\hline $\mathrm{CD}$ at $5 \%$ & 3.77 & 5.07 & 5.32 & 5.60 & 7.44 & 6.99 & 7.04 & 7.68 \\
\hline
\end{tabular}

*DAT - Days After Transplanting

Results of study revealed that Calendula reached the flower bud initiation stage earliest (23.25 DAT) and showed resultant earlier flower bud development (32.88 DAT) and full blooming (35.50 DAT) as well as wilting of flowers (43.00 DAT) under open field condition. Delayed flowering was observed in Antirrhinum (74.67 DAT) while delayed wilting was observed with Helichrysum (94.30 DAT) under polyhouse situation. Least time period required to reach FBD from FBI was observed in candytuft $(6.17$ days), blooming from FBD in Lupin (1.50 days) and wilting of flowers from blooming was recorded in Californian poppy $(2.00$ days) under polyhouse, whereas, highest time period required from FBI to FBD was noticed in Cornflower (19.60 days) under open field, from FBD to blooming in Helichrysum (6.57 days) under polyhouse and from blooming to wilting in Helichrysum (21. 84 days) in open field condition (Table3).

Annuals showed marked variation to reach into their reproductive phase classifying them as early flowering, mid-season flowering or late bloomers. However, this is well established since time immemorial but the quantitative measurements of these durations were lacking. Moreover, the changes in duration under varied growing conditions also represent the physiological changes within the species as an influence of the growing environment. In this experiment all the winter ornamental annual species except 
Table 4 Grouping of genotypes on the basis of FBI and FBI to FBD

\begin{tabular}{|c|c|c|c|c|c|c|c|}
\hline & & Mea & ns with the same let & & not sign & ificantly & different \\
\hline & & en $\mathrm{f}$ & eld condition & & & olyhous & condition \\
\hline 't' grou & ping & & Genotypes & & groupin & & Genotypes \\
\hline & A & & Lupin & & & A & Antirrhinum \\
\hline B & A & & Larkspur & & & B & Petunia \\
\hline B & A & $\mathrm{C}$ & Petunia & & $\mathrm{C}$ & B & Californian Poppy \\
\hline B & $\mathrm{D}$ & $\mathrm{C}$ & Antirrhinum & & $\mathrm{C}$ & B D & Ice Plant \\
\hline B E & $\mathrm{D}$ & $\mathrm{C}$ & Californian Poppy & & C E & B D & Brachycome \\
\hline B E & $\mathrm{D}$ & $\mathrm{C}$ & Dianthus & $\mathrm{F}$ & C E & B D & Daisy \\
\hline B E & $\mathrm{D}$ & $\mathrm{C}$ & Brachyeome & $\mathrm{F}$ & C E & G D & Dimorphotheca \\
\hline $\mathrm{E}$ & $\mathrm{D}$ & $\mathrm{C}$ & Shirley Poppy & $\mathrm{F}$ & $\mathrm{E}$ & G D & Pansy \\
\hline F $\quad E$ & $\mathrm{D}$ & & Phlox & $\mathrm{F}$ & $\mathrm{H} \quad \mathrm{E}$ & $\mathrm{G}$ & Larkspur \\
\hline $\mathrm{F} \quad \mathrm{E}$ & $\mathrm{G}$ & & Sweet William & $\mathrm{F}$ & $\mathrm{H}$ & $\mathrm{G}$ & Phlox \\
\hline $\mathrm{F}$ & $\mathrm{G}$ & $\mathrm{H}$ & Dimorphotheca & $\mathrm{F}$ & $\mathrm{H}$ & $\mathrm{G}$ & Helichrysum \\
\hline & $\mathrm{G}$ & $\mathrm{H}$ & Daisy & & $\mathrm{H}$ & $\mathrm{G}$ & Shirley Poppy \\
\hline & $\mathrm{G}$ & $\mathrm{H}$ & Ice Plant & & $\mathrm{H}$ & I & Cornflower \\
\hline & G & $\mathrm{H}$ & Helichrysum & & $\mathrm{H}$ & I & Dianthus \\
\hline & I & $\mathrm{H}$ & Sweet Pea & & $\mathrm{J}$ & I & Coreopsis \\
\hline $\mathrm{J}$ & I & & Coreopsis & & $\mathrm{J}$ & $\mathrm{K}$ & Sweet William \\
\hline $\mathrm{J}$ & & & Candytuft & & $\mathrm{J}$ & $\mathrm{K}$ & Sweet Pea \\
\hline $\mathrm{J}$ & & & Cornflower & & $\mathrm{L}$ & $\mathrm{K}$ & Lupin \\
\hline & $\mathrm{K}$ & & Pansy & & $\mathrm{L}$ & $\mathrm{K}$ & Candytuft \\
\hline & $\mathrm{K}$ & & Calendula & & $\mathrm{L}$ & & Calendula \\
\hline
\end{tabular}

\begin{tabular}{|c|c|c|c|c|c|c|c|c|}
\hline & & Mear & FBI $\mathrm{s}$ with the same lett & & & & & ntly different \\
\hline & & en fie & $\mathrm{d}$ condition & & & olyh & ous & condition \\
\hline & grou & ping & Genotypes & & roup & ping & & Genotypes \\
\hline & A & & Cornflower & & & A & & Coreopsis \\
\hline B & A & & Coreopsis & $\mathrm{B}$ & & A & & Cornflower \\
\hline B & A & & Helichrysum & B & & & & Larkspur \\
\hline B & A & & Larkspur & $\mathrm{B}$ & & & & Helichrysum \\
\hline B & $\mathrm{C}$ & & Dimorphotheca & & & $\mathrm{C}$ & & Ice Plant \\
\hline $\mathrm{D}$ & $\mathrm{C}$ & & Sweet William & $\mathrm{D}$ & & $\mathrm{C}$ & & Antirrhinum \\
\hline $\mathrm{D}$ & $\mathrm{C}$ & $\mathrm{E}$ & Ice Plant & $\mathrm{D}$ & & $\mathrm{C}$ & $\mathrm{E}$ & Shirley Poppy \\
\hline $\mathrm{D}$ & & $\mathrm{E}$ & Shirley Poppy & $\mathrm{D}$ & & $\mathrm{C}$ & $\mathrm{E}$ & Phlox \\
\hline D & & E & Antirrhinum & $\mathrm{D}$ & & $\mathrm{C}$ & E & Calendula \\
\hline D & & E & Brachycome & $\mathrm{D}$ & & $\mathrm{C}$ & E & Sweet William \\
\hline D & & E & Dianthus & $\mathrm{D}$ & & $\mathrm{C}$ & E & Dianthus \\
\hline D & $\mathrm{F}$ & $\mathrm{E}$ & Phlox & $\mathrm{D}$ & $\mathrm{F}$ & $\mathrm{C}$ & E & Californian Poppy \\
\hline D & $\mathrm{F}$ & E & Sweet Pea & $\mathrm{D}$ & $\mathrm{F}$ & $\mathrm{C}$ & E & Dimorphotheca \\
\hline D & $\mathrm{F}$ & E & Calendula & $\mathrm{D}$ & $\mathrm{F}$ & $\mathrm{C}$ & E & Sweet Pea \\
\hline D & $\mathrm{F}$ & E & Lupin & $\mathrm{D}$ & $\mathrm{F}$ & & E & Brachycome \\
\hline & $\mathrm{F}$ & $\mathrm{E}$ & Californian Poppy & & $\mathrm{F}$ & & $\mathrm{E}$ & Pansy \\
\hline & $\mathrm{F}$ & E & Pansy & & $\mathrm{F}$ & & E & Petunia \\
\hline & $\mathrm{F}$ & E & Candytuft & & $\mathrm{F}$ & & E & Lupin \\
\hline & $\mathrm{F}$ & E & Petunia & & $\mathrm{F}$ & & E & Daisy \\
\hline & $\mathrm{F}$ & & Daisy & & $\mathrm{F}$ & & & Candytuft \\
\hline
\end{tabular}

Sweet William and Lupin takes higher time period to reach the FBI under polyhouse cultivation as compared to the open field condition. As compared to both the cases Calendula showed the earliest FBI whereas the delayed effect was found variable as in open field condition, Lupin reached the FBI stage last of all (51.03 DAT) and in polyhouse condition Antirrhinum reached the FBI stage last of all (74.67 DAT). Findings of present study are in close conformity with Cavins et al. (2000), the author reported that warmer greenhouses in each year extended production time for Antirrhinum.

Based on the results through the ' $t$ ' grouping of LSD means, the genotypes reflected 12 classes of data under polyhouse condition as compared to 10 under open field (Table 4) showed more heterogeneity of growth of winter annuals under protected condition. Groping of genotypes resulted ten winter annuals out of twenty (Helichrysum, Larkspur, Sweet William, Lupin, Brachycome, Cornflower, Dimorphotheca, Dianthus, Candytuft and Sweet Pea) required higher time period to attain FBD from FBI under open field as compared to polyhouse. Although, data pertaining from the table 4 showed that in both the cases genotypes were grouped into 6 (Table 4 ) but wide variation in the growth of flower bud was also noticed as the same species were not grouped in a similar pattern showing differential response to agro-climatic and microclimatic condition. However, only 8 winter annuals (Ice plant, Antirrhinum, Calendula, Lupin, Brachycome, Californian Poppy, Coreopsis and Sweet Pea) took maximum time period to reach the blooming stage under open field condition than polyhouse. Data presented in Table 5, on the basis of growth of flower buds showed 8 classes under protected condition as compared to 7 classes under open field situation reflecting wider heterogeneity of flower bud maturity by the genotypes under polyhouse situation might be due to differential response to microclimate. It was found that the in-situ longevity of flowers under open field was found better than polyhouse condition except Sweet Pea, Candytuft, Shirley poppy, Dimorphotheca, Lupin, Petunia and Sweet William. Grouping of genotypes showed marked variation within the genotypes and it is also become useful to select the relative placement of annuals in several garden components, herbaceous borders and in outdoor landscaping.

In any landscaping condition synchronized blooming is an essential principle to use its best effect along with color combination of winter annuals (Lindgren et al., 2007; Love et al., 2009). The current experiment gave the precise database of the comparative performance of twenty different winter annuals with respects to the duration between the major stages of flowering in 
Table 5 Grouping of genotypes on the basis of FBD to Blooming

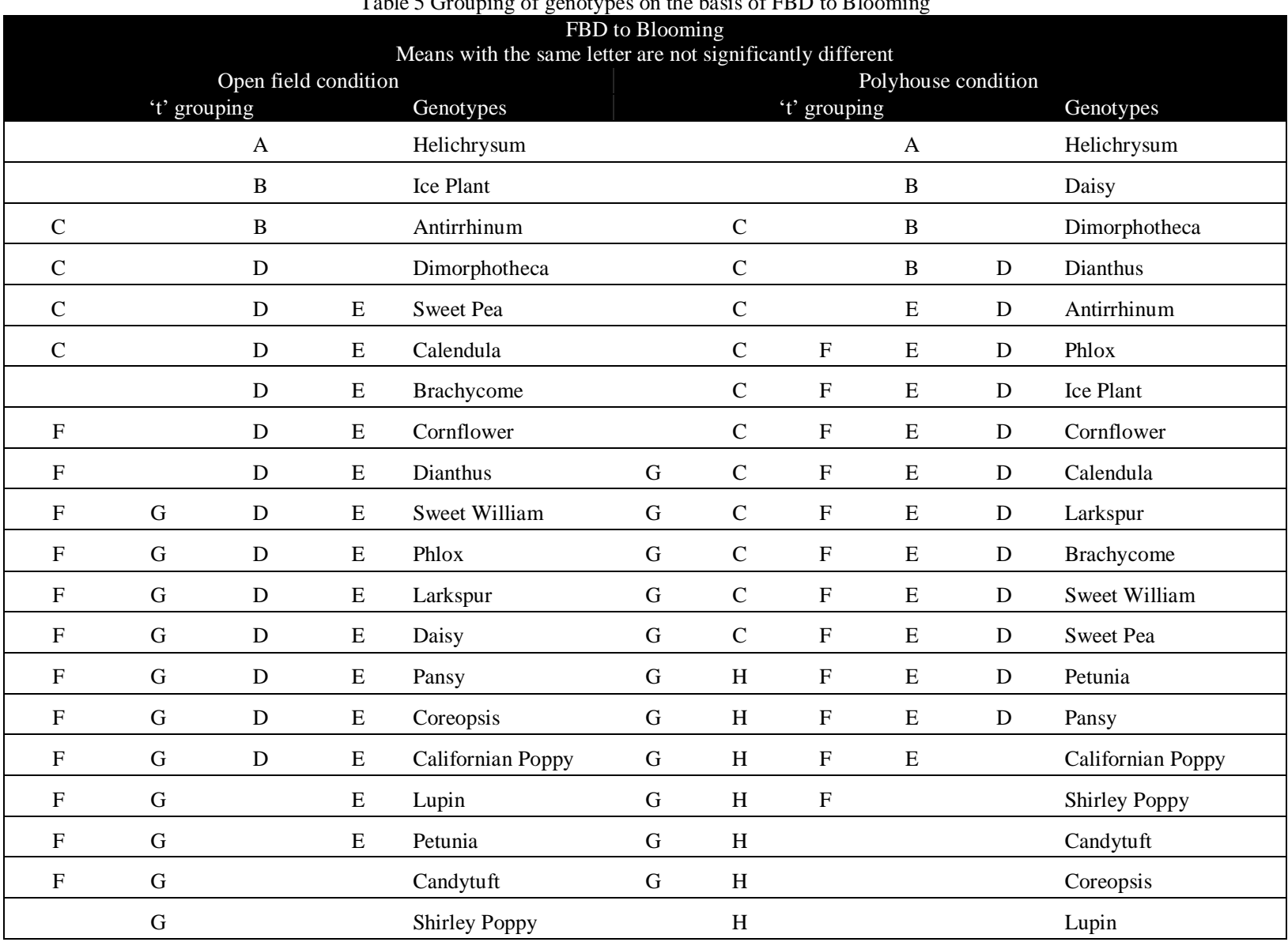

both ways from the day after transplanting as well as from the preceding stage. This experiment was performed to provide the information about winter annuals for the growers to sow the late bloomers well ahead with a quantitative measurement. Various researchers also found that the species-wise variation regarding different durations might be due to the combination of several factors like environmental stimuli, inherent growth pattern, soil condition, genotypic configuration of the species (Munir et al., 2004; Inaba \& Ohshiro, 2005; Ibrahim et al., 2010; Ali, 2013). Apart from that, the variation in maturity was observed due to the effect of temperature under different growing conditions during flowering period (Niu et al., 2000; Kang \& Iersel, 2001; Niu et al., 2006; Warner, 2010). Fluctuation in flowering behavior under open and protected condition was observed in this experiment due to temperature and light quality was corroborated by the observations of Kumar \& Kaur (2000) and Warner \& Erwin (2002) also noticed significant variation in FBI and other phases of flower development within the different ornamental annual species.

\section{Conclusion}

The results obtained from the present experiment revealed that the variability exists within the genotypes under each growing environment or in the same genotype under different growing conditions. To exert the best effect in any landscaping situation, especially in herbaceous borders - simultaneous blooming is an essential principle with color combination. To achieve this objective, it is essential to categorize the plants accordingly by comparing its flowering habit and colour combination.

\section{Conflict of Interest}

No conflict of interest.

\section{References}

Ali MA (2013) Effect of different concentrations (NPK) on growth and flowering of Helichrysum bracteatum. International Journal of Agriculture and Crop Sciences5: 1966-1968. 
Bhattarai B, Maitra S, Thokchom R (2019) Assessment of Height, Earliness and Biomass Production in Selected Winter Flowering Ornamental Annuals for Better Utilization in Landscaping. The Pharma Innovation 8: 59-64

Boldt JK, Atland JE (2019) Timing of short -term reduction in temperature and irradiance affects growth and flowering of four annual bedding plants. Horticulturae 5: 15 https://doi.org/10.3390/horticulturae5010015.

Brown SH (2012) Colorful plant beds for South Florida and similar climates. Lee County Extension, Fort Myers, Florida 239: 533-7513.

Cavins TJ, Dole JM, Stamback V (2000) Unheated and minimally heated winter greenhouse production of specialty cut flower. Horticulture Technology 10: 793-799.

Dhatt KK, Kumar R(2007) Effect of planting time and spacing on plant growth, flowering and seed yield in Coreopsis lanceolataand Coreopsis tinctoria. Journal of Ornamental Horticulture10: 105-109.

Ibrahim SMM, Taha LS, Farahat MM (2010) Influence of foliar application of Peptone on growth, flowering and chemical composition ofHelichrysum bracteatumplants under different irrigation intervals. Ozean Journal of Applied Sciences 3: 143-155.

Inaba Z, Ohshiro M (2005) Effects of planting density and methods of raising seedlings on flowering, yield and quality of cut flowers in snapdragons (Antirrhinum majus L.). Environment Control in Biology 43: 201-210.

Kanamadi VC, Dharmatti PR, Patil S, Gangadharappa PM, Patil BC (1999) Propagation of straw flower (Helichrysum bracteatum Andr.) by stem cuttings. Advances in Plant Science Research in India 9:113-115.

Kang JG, Iersel MWV (2001) Interactions between temperature and fertilizer concentration affect growth of subirrigated petunias. Journal of Plant Nutrition 24: 753-765.

Kazinczi G, Hunyadi K, Lukacs D (1999) Data on the biology of Cornflower (Centaurea cyanus L.) I. Germination biology and growth analysis. Novenyvedelem 35: 45-52.

Krogt TVD (1980) The flowering of Sweet Williams in the winter. Vakbladvoor de Bloemisterij 35: 34-35.

Kumar R, Kaur K (2000) Effect of planting time and cultivars on growth, flowering and seed yield in Phlox (Phlox drummondii). Seed Research 28: 23-26.

Lindgren DT, Streich AN, Todd KA, Rodie SN(2007) Annuals for
Nebraska Landscape, I. Flowering plants. University of NebraskaLincoln Extension. http://ianrpubs.unl.edu/live/g1774/build/g1774.pdf.

Love SL, Noble K, Parkinson S, Bell S (2009) Herbaceous ornamentals: annuals, perennials and ornamental grasses. Short-Season, high altitude gardening 1-16. http://www.cals.uidaho.edu/edcomm/pdf/bul/bul0861.pdf.

Mattson NS, Erwin JE (2003) Temperature affects flower initiation and development rate of Impatiens, Petunia, and Viola. Acta Horticulturae 624: 191-197.

McDaniel CN, Singer SR, Smith SME (1992) Developmental states associated with the floral transition. Developmental Biology 153: 59-69.

Mili R, Sable AS (2003) Effect of planting density and nitrogen levels on growth and flower production of Calendula (Calendula officinalis L.). Indian Journal of Horticulture 60: 399-403.

Munir M (2003) A study on the effects of environmental factors affecting the phases of flower development in Antirrhinum majus L..Ph.D. Thesis submitted to the Department of Horticulture and Landscape, School of Plant Sciences, The University of Reading, United Kingdom.

Munir M, Jamil M, Baloch JUD, Khattak KR (2004) Growth and flowering ofAntirrhinum majus $\mathrm{L}$. under varying temperatures. International Journal of Agriculture and Biology 6: 173-178.

Murfet IC (1977) Environmental interaction and genetics of flowering. Annual Review of Plant Physiology 28: 253-278.

Niu G H, Heins RD, Cameron AC, Carlson WH (2000) Day and night temperatures, daily light integral and $\mathrm{CO}_{2}$ enrichment affect growth and flower development of pansy (Viola $x$ wittrockiana). Journal of the American Society for Horticultural Science 125: 436-441.

Niu GH, Rodriguez DS, Wang YT (2006) Impact of drought and temperature on growth and leaf gas exchange of six bedding plant species under greenhouse conditions. Hort Science 41: 1408-1411.

Randhawa GS, Mukhopadhyay A (1986) Floriculture in India. Allied Publishers Private Limited, 58-60.

Shang H, Deitzer GF, Cox LJD (2003) Differential temperature (DIF) effects on the growth, morphology and flowering of Antirrhinum majus L. (Snapdragon) cultivars. Acta Horticulturae 624: $177-183$.

Singh AK (2005) Growth and seed yield in California poppy (Eschscholtzia californica Chamisso) as influenced by plant growth regulators. Journal of Ornamental Horticulture 8: 159-160.

Journal of Experimental Biology and Agricultural Sciences http://www.jebas.org 
Warner RM (2010) Temperature and photoperiod influence flowering and morphology of four Petunia spp. HortScience 45: 365-368.

Warner RM, Erwin JE (2002) Photosynthetic responses of heattolerant and heat-sensitive cultivars of Impatiens hawkeri and Viola $x$ wittrockiana to high temperature exposures. Acta Horticulturae 580: 215-219.
Warner RM, Erwin JE (2006) Prolonged high temperature exposure differentially reduces growth and flowering of 12 Viola $x$ wittrockiana Gams. cvs. ScientiaHorticulturae108: 295-302.

Zheng ZL, Yang Z, Jang JC, Metzger JD (2006) Phytochromes $\mathrm{A} 1$ and $\mathrm{B} 1$ have distinct functions in the photoperiodic control of flowering in the obligate long day plant Nicotiana sylvestris. Plant Cell \& Environment 29: 1673-1685. 